[Agr. Biol. Chem., Vol. 27, No. 7, p. 507 517, 1963]

\title{
Degradation of Nucleic Acids and their Related Compounds by Microbial Enzymes
}

\author{
Part IX. Degradation of Ribonucleic Acid and Deoxyribonucleic \\ Acid by Intracellular Enzymes of Rhodotorula glutinis.*
}

\author{
By Yoshio Nakao, Ikuo Nogami and Kôichi Ogata** \\ Research Laboratories, Takeda Chemical Industries, Ltd., Osaka \\ Received February 28, 1963
}

\begin{abstract}
Rhodotorula glutinis produced three kinds of RNA-depolymerases, namely RNA-depolymerases I, II and III, DNA-depolymerase, phosphodiesterase, capable of hydrolyzing CaDNPP and phosphomonoesterase in the cells. Of the three RNA-depolymerases produced by Rhodotorula glutinis, RNA-depolymerase I hydrolyzed RNA into 5'-mononucleotide and RNA-depolymerase II and III degraded RNA into 3 '-mononucleotides. RNA-depolymerase I was produced in the cells at the early stage of the logarithmic phase of growth but RNA-depolymerase II and III were produced during the late logarithmic and the early stationary phase of growth. DNA-depolymerase was produced in the cells at the early stage of the logarithmic phase of growth and hydrolyzed DNA into $5^{\prime}$-deoxymononucleotides and deoxyoligonucleotides.
\end{abstract}

\section{INTRODUCTION}

The authors reported previously that Rhodotorula glutinis produced two kinds of extracellular enzymes which hydrolyzed RNA into $3^{\prime}$-mononucleotides ${ }^{1)}$. Higuchi and Uemura $^{2)}$ suggested the existence of the intracellular RNase by their observation that mono-, oligo-, and polynucleotides possessing terminal phosphate in the 3 '-position were excreted from the washed cells of Saccharomyces cerevisiae. Ôtaka and $\mathbf{U c h i d a}^{3)}$ reported that Saccharomyces cerevisiae produced intracellular RNase which hydrolyzed RNA

\footnotetext{
Abbreviations used are : PMase, phosphomonoesterase; PDase, phosphodiesterase. Others are the same as described in the previous paper ${ }^{11}$.

* The report was presented at the General Meeting of the Agricultural Chemical Society of Japan, Fukuoka, April 1, 1961.

** Present address, Department of Agricultural Chemistry, Kyoto University, Kyoto.

1) Y. Nakao and K. Ogata, This Journal, 27, 499 (1963).

2) M. Higuchi and T. Uemura, J. Agr. Chem. Soc. 33, 304, 821, 826 (1959).

3) Y. Ôtaka and K. Uchida, Abstracts of papers presented at the Meeting of the Institute of Physical and Chemical Research, Tokyo, December 7, 1960, p, 11 .
}

into 3'-mononucleotides. However, we have so far had very little information as to the yeast RNA-depolymerase which catalyzes the degradation of RNA into 5'-mononucleotides. On the other hand, yeast DNase $^{4}$ was investigated in relation to the mechanism by which the degradation of DNA was regulated within the cell. But the products of hydrolysis of DNA by yeast DNase have never been clear.

In the present work, studies were made on the degradation of RNA and DNA by the intracellular enzymes of Rhodotorula glutinis. As a result, it was found that the microorganism produced in the cells RNA-hydrolyzing enzymes one of which degraded RNA into 5'-mononucleotides and another into $3^{\prime}$ mononucleotides, and that the activities of the enzymes changed during growth of the

4) S. Zamenhof and E. Chargaff, J. Biol. Chem., 180, 727 (1949). 
microorganism. DNA-depolymerase capable of hydrolyzing DNA into 5'-deoxymononucleotides was also found in the cells. The results are presented in detail in the following.

\section{EXPERIMENTAL}

\section{Materials and Methods.}

Organism. Rhodotorula glutinis IFO 0559.

Medium. One liter of NS-medium contained glucose $50.0 \mathrm{~g}$, peptone $5.0 \mathrm{~g}$, beef extract $5.0 \mathrm{~g}$, yeast extract $2.0 \mathrm{~g}, \mathrm{MgSO}_{4} \cdot 7 \mathrm{H}_{2} \mathrm{O} 0.5 \mathrm{~g}, \mathrm{CaCl}_{2} \cdot 2 \mathrm{H}_{2} \mathrm{O} 0.1 \mathrm{~g}$, and $\mathrm{KNO}_{3} 2.0 \mathrm{~g}$. The $\mathrm{pH}$ was adjusted to 7.0 before sterilization. This medium was designated in this paper as NS-medium. The above medium supplemented with $0.5 \%$ soy bean meal was also used which was named Mix-medium.

Preparation of Enzyme Solution. Unless otherwise stated, Rhodotorula glutinis was grown at $28^{\circ} \mathrm{C}$ in the medium described above for 96 hours on a reciprocating shaker. The cells were harvested by centrifugation, washed twice with cold distilled water, and suspended in distilled water to give one-third volume of the initial cultured broth. The cell suspension was sonicated by a Sakuma SV-505 $10 \mathrm{KC}$ osillator for 30 minutes in the cold and centrifuged at 3000 r.p.m. for 10 minutes to remove cell debris and unbroken cells. The resultant supernatant solution was used as the enzyme solution.

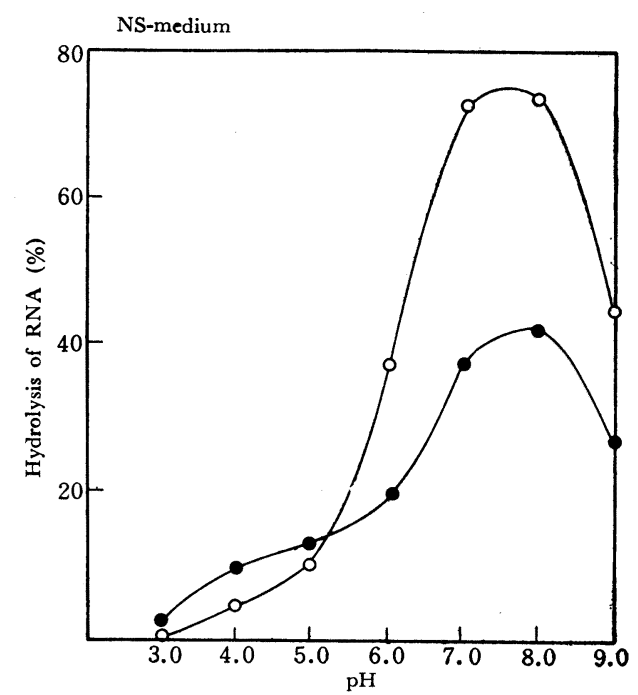

Analytical method: RNA and DNA were determined by the method of Ogur-Rosen ${ }^{5)}$. Other methods used in this work were the same as described in the preceding paper').

\section{RESULTS}

(I) pH-Activity Curves of the Enzymes Participating in the Degradation of Nucleic Acids.

(A) RNA-depolymerase. Rhodotorula glutinis was cultivated in NS-medium and in Mixmedium for 16 and 96 hours, respectively, and the activity of the intracellular RNAdepolymerase was measured in the $\mathrm{pH}$ range between 3.0 and 9.0 .

As shown in Fig. 1, the optimum $\mathrm{pH}$ of the RNA-depolymerase obtained from the cells after 16-hours cultivation in NS-medium was around 7.0 and continuation of the cultivation resulted in a decrease in the activity. The optimum $\mathrm{pH}$ of the RNA-depolymerase obtained from the cells after 16-hour cultivation in Mix-medium was about 7.0 , and two RNA-depolymerases were present in the cells after 96-hour cultivation in the same medium. One of the enzyme was most active at $\mathrm{pH} 5.0$, the other at $\mathrm{pH}$ 7.0. The enzyme

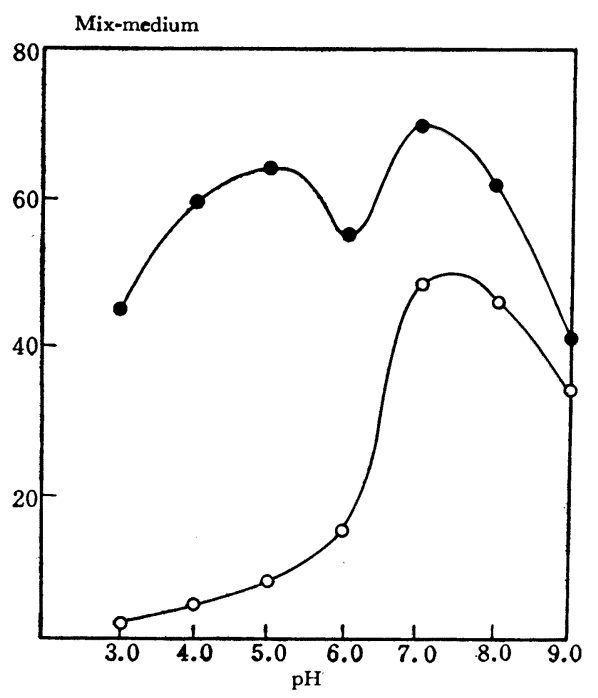

FIG. 1. Effect of $\mathrm{pH}$ on the Hydrolysis of RNA.

Hydrolysis of RNA by the sonicate of the cells from 16-hour cultivation (-O-), and 96-hour cultivation (- $\longrightarrow$ ).

5) M. Ogur and G. Rosen, Arch. Biochem., 25, 262 (1950). 
the both media for 16 and 96 hours was optimally active at around $\mathrm{pH}$ 8.0.

(C) Phosphodiesterase. Figure 3 illustrates the results obtained. The optimum for the hydrolysis of CaDNPP was at about $\mathrm{pH}$ 8.0.

(D) Phosphomonoesterase. The sonic extract of the cells obtained from 96-hour culture in NS-medium was used as the enzyme solution and the activity of the phosphomonoesterase was measured. As is clear from the results shown in Fig. 4, the optimum $\mathrm{pH}$ was 5.0 and the rate of hydrolysis of the substrate increased in the order of $5^{\prime}$-AMP, $\beta$-glycerophosphate and 3'-AMP.

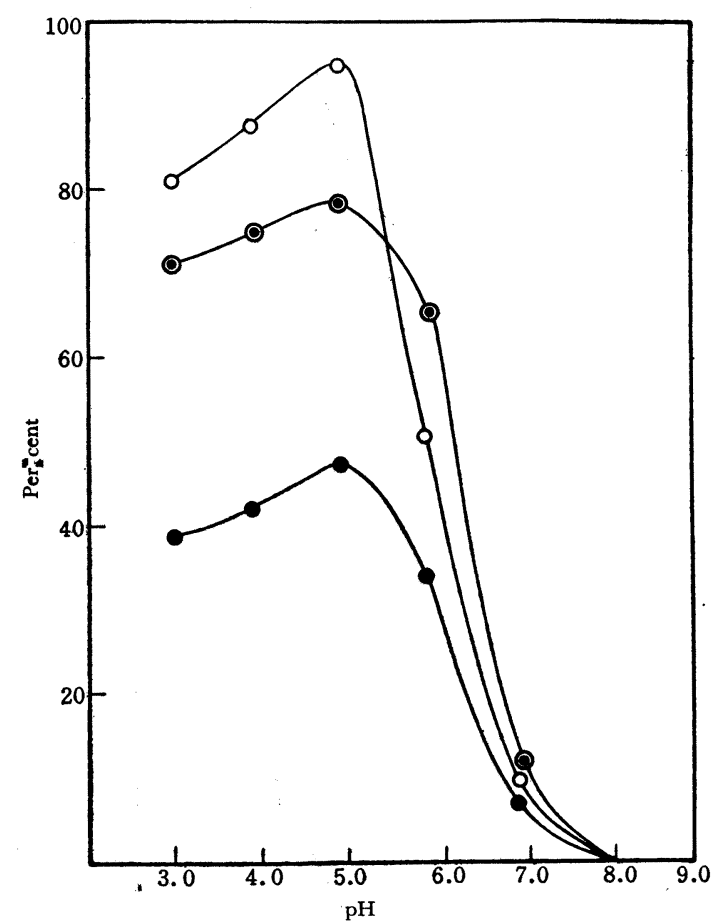

Fig. 4. Effect of $\mathrm{pH}$ on Phosphomonoesterase Activity.

Hydrolysis of 3'-AMP (-O-), 5'-AMP (- -); and $\beta$-glycerophosphate (-O-).

(E) Deaminase. Investigation was made on the activity of adenylic, guanylic and cytidylic deaminases and it was concluded that the microorganism did not produce these deaminases during growth.

(II) Changes in the Enzyme Activities During Growth.

Rhodotorula glutinis was cultivated in NSmedium at $28^{\circ} \mathrm{C}$ and the activities of various enzymes in the cells were determined at different stages of growth. The results are shown in Fig. 5. Both phosphomonoesterase and phosphodiesterase activities increased in proportion to the growth and the maximum formation of the two enzymes per unit of the dry cell weight was reached in 48 hours in the former case and in 96 hours in the latter. On the other hand, very high activity of RNA-depolymerase I was found in the early logarithmic phase of growth and at the onset of the stationary phase the activity was very low. Change in DNA-depolymerase activity was similar to that in RNA-depolymerase I activity. Then investigation was made on the relation between RNA-depolymerase I activity and the RNA content. As shown in Fig. 6, the RNA-depolymerase I activity reached the sharp maximum which corresponded to the maximum amount of RNA in the cells. These results suggest that high RNA-depolymerase I activity is closely associated with phases of growth and the enzyme has a relation with the metabolism of RNA.

(III) Products of RNA Hydrolysis by Various RNAdepolymerases in the Cells.

As mentioned above, Rhodotorula glutinis produced RNA-depolymerase I, II and III when cultivated in Mix-medium, so investigation was made on the products of RNA hydrolysis by these enzymes. Rhodotorula glutinis was cultivated in Mix-medium at $28^{\circ} \mathrm{C}$ for 16,40 and 96 hours and enzyme solutions were prepared from the resulting cells. RNA was hydrolyzed by the enzyme solutions in the $\mathrm{pH}$ range between 3.0 and 9.0 and the rates of RNA degradation, orthophosphate liberation, 5'-mononucleotide and 


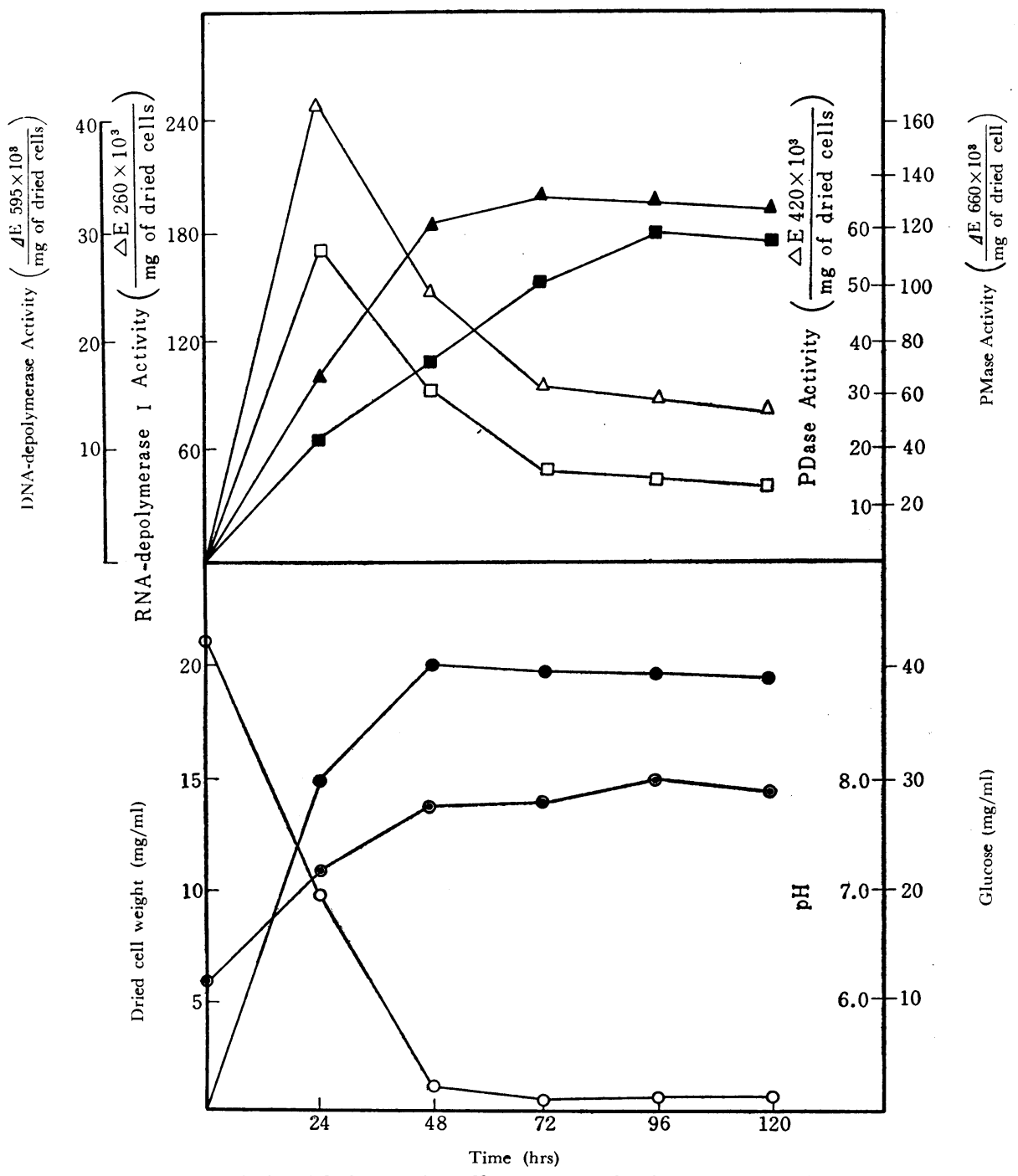

FIG. 5. Variation of the Various Enzymes Production as a Function of Time. $\underset{\text { depolymerase; }}{-\mathrm{PH}}-\longrightarrow-\mathrm{O}-$ phosphomonoesterase; - , dried cell weight; $-\triangle \longrightarrow$, phosphodiesterase.

3'-mononucleotide formation were determined. Figures $7-\mathrm{a}, \mathrm{b}$, and $\mathrm{c}$ show the results obtained.

RNA was hydrolyzed into $5^{\prime}$-mononucleotides optimally at $\mathrm{pH} 7.0$ by the sonic extract of the cells obtained after 16-hour cultivation. This fact indicates that RNA-depolymerase I degrades RNA into 5'-mononucleotides. The cells after 40-hour cultivation contained an enzyme which degraded RNA into 3'-mononucleotides at $\mathrm{pH} 5.0$ and another enzyme which hydrolyzed RNA into $3^{\prime}$ - and 5'-mononucleotides at $\mathrm{pH}$ 7.0. There existed two kinds of RNA-depolymerases in the cells obtained after 96-hour cultivation, one of them degraded RNA into 3'-mononucleotides at 


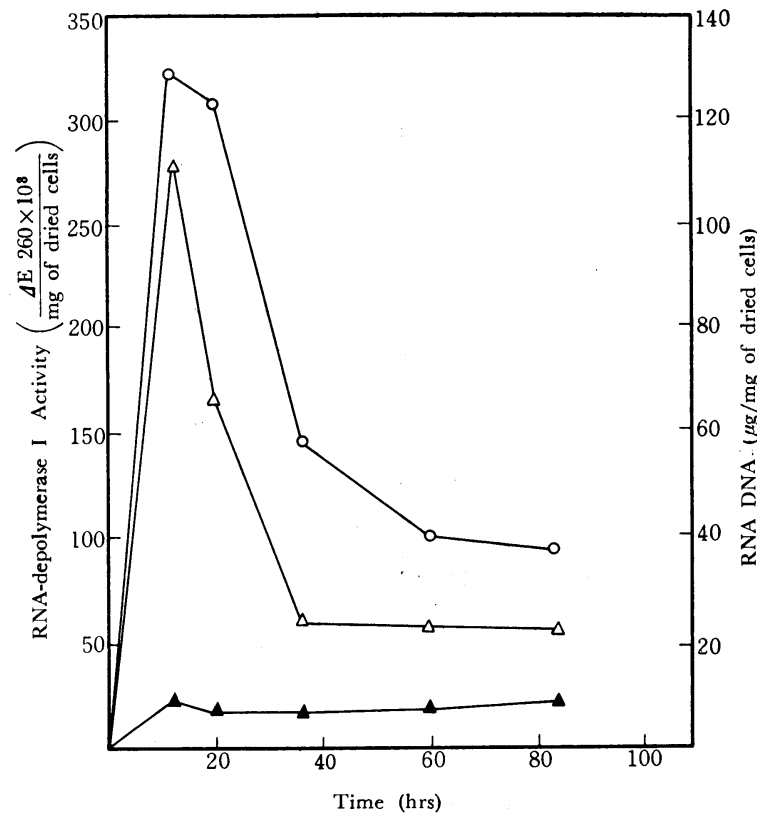

FIG. 6. Changes in RNA-Depolymerase I Activity and the Amounts of RNA and DNA in the Cells During Growth.

Rhodotorula glutinis was cultivated in NS medium at $28^{\circ} \mathrm{C}$ and the follows were determined at different stages of growth.

$-\mathrm{O}-$, RNA-depolymerase I; $-\triangle \longrightarrow$, RNA; - - - DNA.

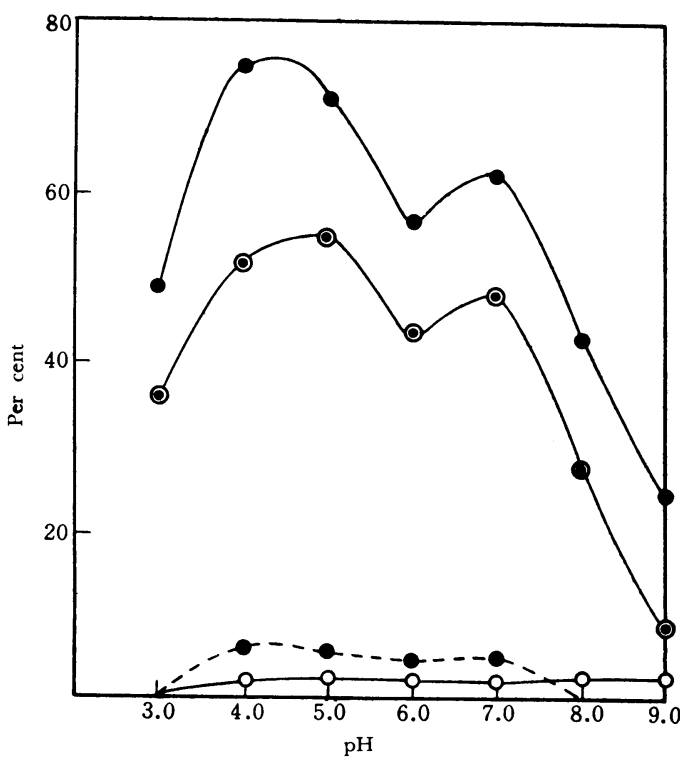

FIG. 8. Hydrolysis of RNA and the Formation of Mononucleotides at Various $\mathrm{pH}$ Values in the Presence of Arsenate.

Mixtures of $0.5 \mathrm{ml}$ of $2.0 \%$ RNA, $0.8 \mathrm{ml}$ of $0.5 \mathrm{M}$ acetate buffer or $0.5 \mathrm{M}$ Tris buffer of a pH as indicated, $0.2 \mathrm{ml}$ of $0.2 \mathrm{M}$ sodium arsenate and $0.5 \mathrm{ml}$ of the sonicate of the cells from 96-hour cultivation were incubated at $37^{\circ} \mathrm{C}$ for 3 hours. The followings were determined: ——, RNA hydrolysis; ——-, 5'-mono nucleotide formation; _........., orthophosphate liberation.
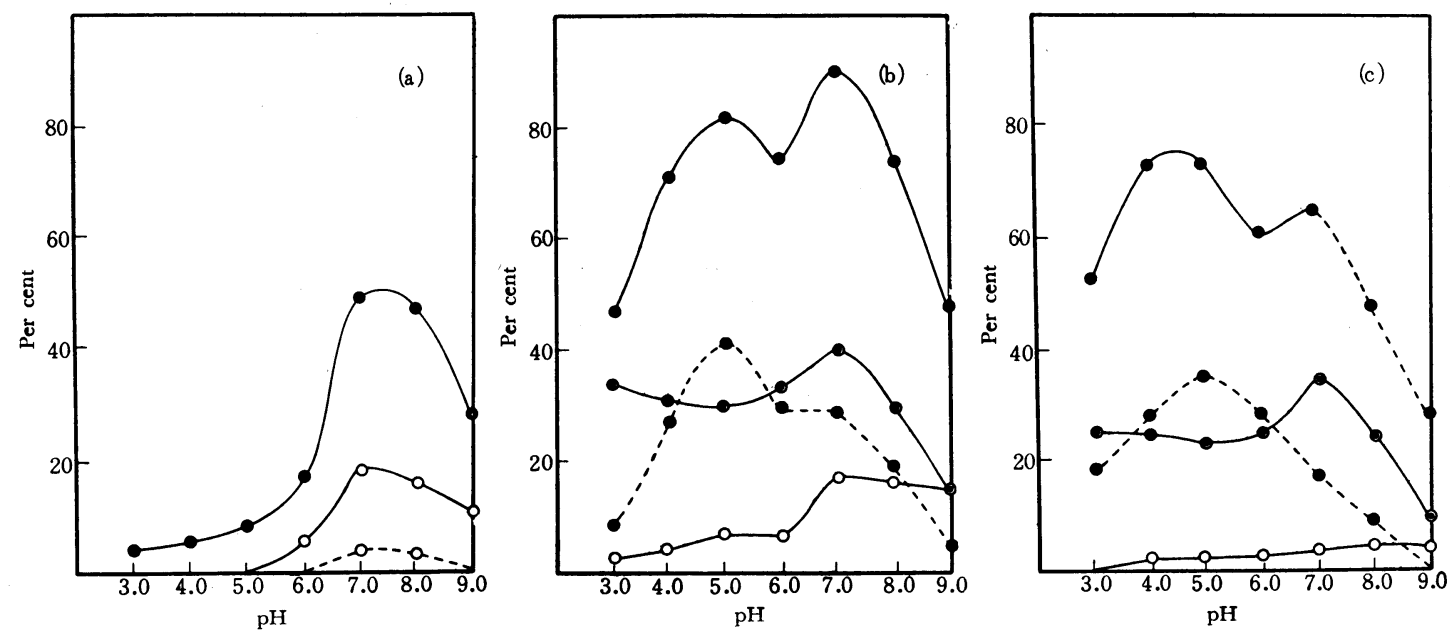

FIG. 7. Effect of $\mathrm{pH}$ on the Degradation of RNA and the Formation of Mononucleotides.

Mixtures of $0.5 \mathrm{ml}$ of $2.0 \% \mathrm{RNA}, 1.0 \mathrm{ml}$ of $0.5 \mathrm{M}$ acetate buffer or $0.5 \mathrm{M}$ Tris buffer of a pH as indicated and $0.5 \mathrm{ml}$ of the sonicate of the cells from 16-hour cultivation (a), 40-hour cultivation (b) and 96-hour cultivation (c) were incubated at

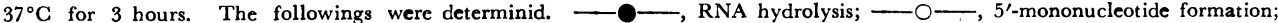
- - , total mononucleotide formation; ....-...., orthophosphate liberation. 
pH 5.0 and the other hydrolyzed RNA into 3'-mononucleotides at $\mathrm{pH}$ 7.0. RNA-depolymerases II and III seem to catalyze the hydrolysis of RNA into 3'-mononucleotides. As is obvious from Figs. 7-b and $\mathrm{c}$ the sonic extracts of cells obtained from 40-hour cultivation as well as those from 96-hour cultivation released much orthophosphate from RNA. In order to clarify the route of the formation of the orthophosphate, RNA was degraded by the sonic extract of the cells obtained from 96-hour cultivation in the presence of $20 \mathrm{~mm}$ of sodium arsenate which was known as an inhibitor of phosphomono- esterase, and the mononucleotides were determined by the enzymatic method. As a result, it was found that 3 '-mononucleotides were produced as degradation products of RNA at any $\mathrm{pH}$ as shown in Fig. 8. Accordingly, the orthophosphate shown in Fig. 7-c is assumed to be formed through 3'-mononucleotides from RNA.

To confirm the results obtained above, the degradation products of RNA were subjected to ion-exchange analysis. A mixture of $2.5 \mathrm{ml}$ of $2.0 \%$ RNA solution, $5.0 \mathrm{ml}$ of $0.5 \mathrm{M}$ Tris buffer ( $\mathrm{pH} 7.3$ ) and $2.5 \mathrm{ml}$ of the enzyme solution which was prepared from the cells

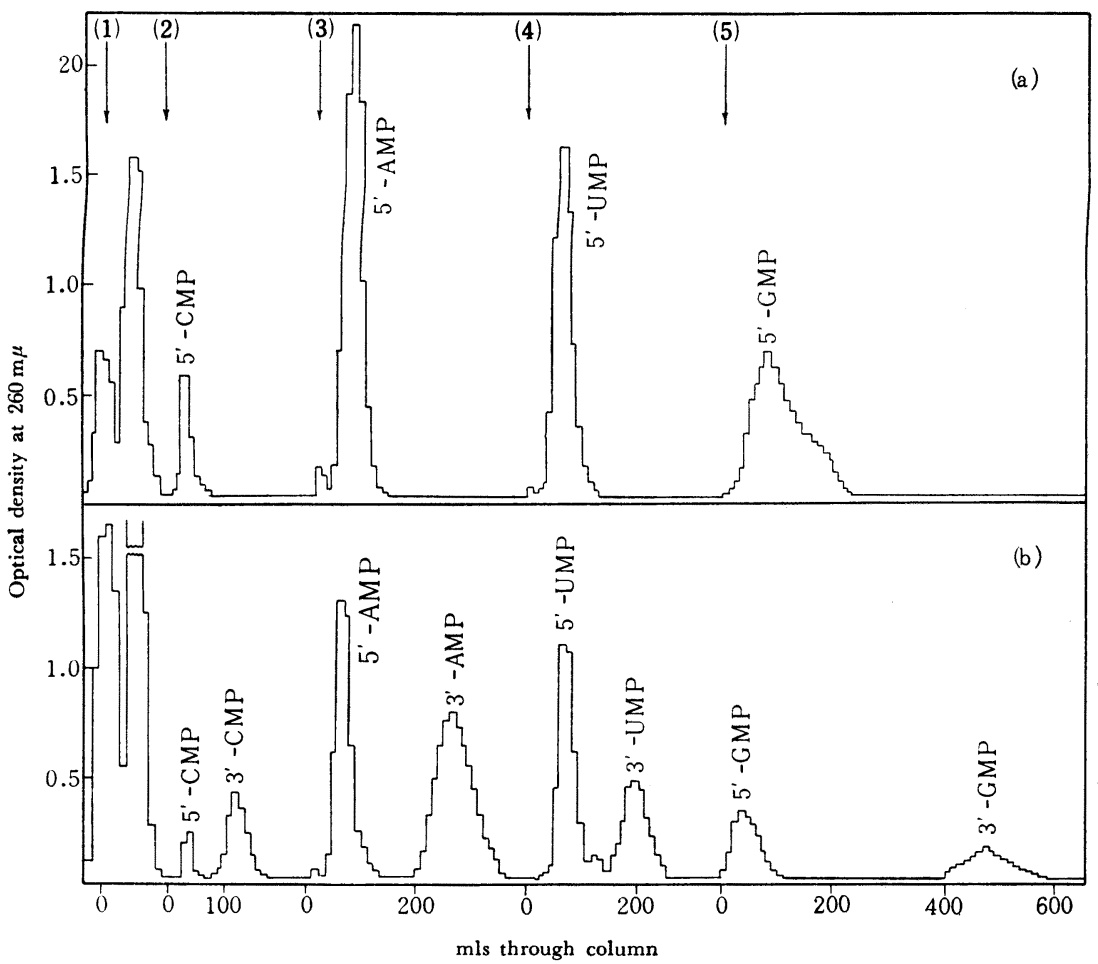

FIG. 9. Separation of Mononucleotides in Enzymatic Digests of RNA by Anion Exchanger.

Exchanger: Dowex-1 $\times 8$-formate, $200 \sim 400$ mesh, $6 \mathrm{~cm} \times 0.79 \mathrm{~cm}^{2}$.

Eluting solution: Formic acid (Formic) and sodium formate (Formate) as shown.

Flow rate: $0.5 \mathrm{ml} / \mathrm{min}$. Fraction size was $10 \mathrm{ml}$.

Adsorbed material: (a) RNA hydrolyzate by the sonicate of the cells from 16-hour cultivation. (b) RNA hydrolyzate by the sonicate of the cells from 40-hour cultivation. See text for additional details.
(1) $0.005 \mathrm{~m}$ Formic
(2) $\left\{\begin{array}{lll}0.01 \mathrm{M} & \text { Formic } \\ 0.05 & \text { Formate }\end{array}\right.$
(2) 0.02 м Formic
(4) $\left\{\begin{array}{lll}0.1 & \text { M Formic } \\ 0.1 & \text { Formate }\end{array}\right.$
(3) 0.1 M Formic 
of 16-hour cultivation in Mix-medium was incubated at $37^{\circ} \mathrm{C}$ for 3 hours and the reaction was stopped by heating the mixture at $100^{\circ} \mathrm{C}$ for 5 minutes. The precipitate was removed by centrifugation. and by the use of $2.0 \mathrm{ml}$ of the supernatant as a sample, the rates of RNA degradation, orthophosphate liberation, and 5'-mononucleotide and 3'mononucleotide formation were estimated.

TABLE I. ANALYSES OF RNA HYDROLYZATES

Sonicate of the cells from

Enzyme solution

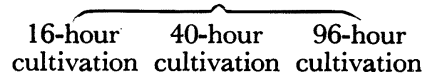

\begin{tabular}{|c|c|c|c|c|}
\hline $\mathrm{pH}$ of degradation & 7.3 & 7.3 & 4.0 & 7.3 \\
\hline $\begin{array}{l}\text { Rate of RNA hydrolysis } \\
(\%)\end{array}$ & 83.0 & 81.0 & 89.0 & 71.5 \\
\hline $\begin{array}{l}\text { Rate of orthophosphate } \\
\text { liberation }(\%)\end{array}$ & 3.5 & 15.5 & 22.5 & \\
\hline $\begin{array}{l}\text { Rate of } 5^{\prime} \text {-mononucleotide } \\
\text { formation }(\%)\end{array}$ & 46.0 & 18.4 & 0 & \\
\hline $\begin{array}{l}\text { Rate of } 2^{\prime}-\left(3^{\prime}\right) \text {-mono- } \\
\text { nucleotide formation }(\%)\end{array}$ & 0 & 15.6 & 44.5 & \\
\hline
\end{tabular}

The result is shown in Table $I$.

Four $\mathrm{ml}$ of the supernatant was analyzed by ion-exchange column chromatography. Figure 9-a illustrates the elution pattern. It seems likely that mononucleotides formed are $5^{\prime}$-isomer. On the other hand, using the sonic extract of the cells obtained from 40 -

TABLE II. PROPORTIONS IN MOLES OF MONONUCLEOTIDES IN RNA HYDROLYZATE BY SONICATES OF CELls ObTained AT VARIOUS GROWTH PHASES

\begin{tabular}{crrrr} 
Cultivation period & $16 \mathrm{hr}$. & $40 \mathrm{hr}$. & \multicolumn{2}{c}{$96 \mathrm{hr}}$. \\
pH of degradation & 7.3 & 7.3 & $\overbrace{4.0}$ & 7.3 \\
5'CMP & 0.23 & 0.24 & - & - \\
5'AMP & 1.00 & 1.00 & - & - \\
5'UMP & 0.96 & 1.26 & - & - \\
5'GMP & 1.25 & 0.84 & - & - \\
3'GMP & - & 0.66 & 1.23 & 0.62 \\
3'AMP & - & 1.00 & 1.00 & 1.00 \\
3'UMP & - & 0.62 & 1.15 & 0.74 \\
3'GMP & - & 0.52 & 1.63 & 0.78
\end{tabular}

Data are expressed in comparative values against 5'AMP and 3'AMP, respectively.

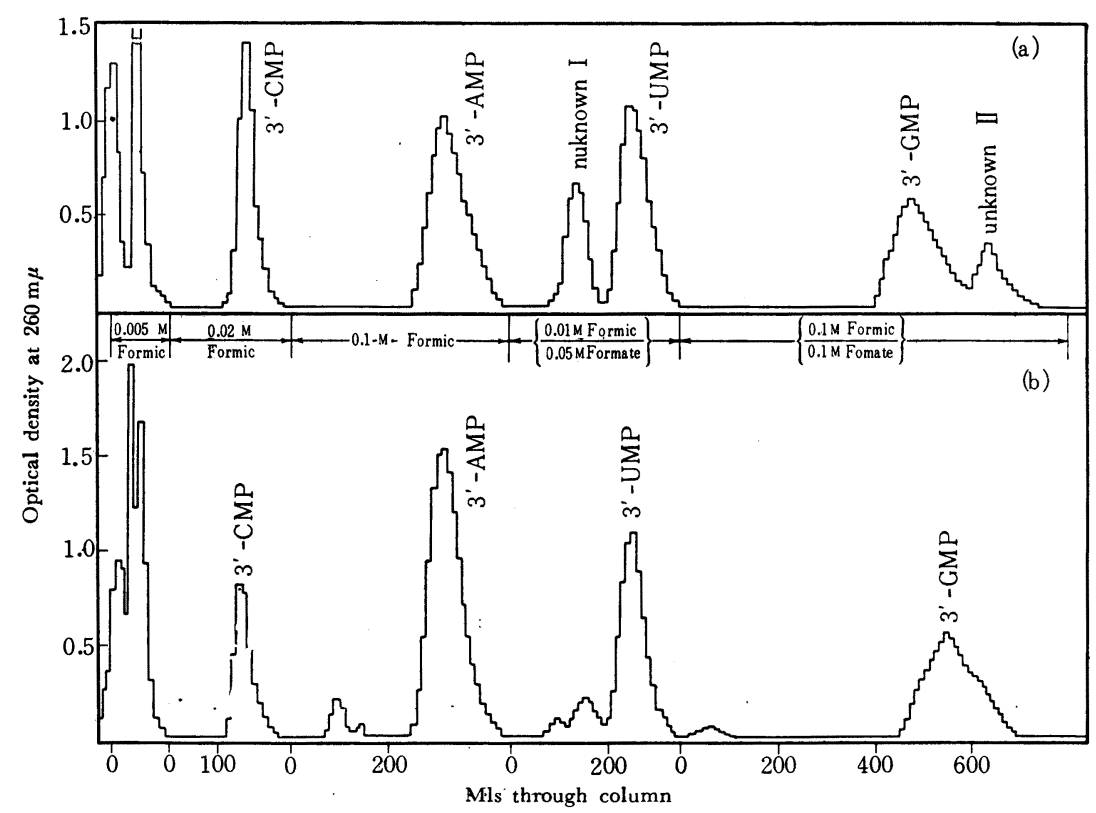

FIG. 10. Separation of Mononucleotides in Enzymatic Digest of RNA by Anion Exchanger.

Exchanger, eluting solution, flow rate and fraction size: see Fig. 9.

Adsorbed material: RNA hydrolyzate by the sonicate of the cells from 96-hour cultivation at $\mathrm{pH} 4.0$ (a) and at $\mathrm{pH} 7.3$ (b). 
hour cultivation in Mix-medium as an enzyme solution, RNA was degraded under the same condition as described above. The ion-exchange chromatogram of $5.0 \mathrm{ml}$ of the reaction mixture is shown in Fig. 9-b. Table I shows the result of the enzymatic assay of the mononucleotides in the hydrolyzate. These results indicate that RNA was degraded into $3^{\prime}$ - and $5^{\prime}$-mononucleotides at $\mathrm{pH} 7.3$ by the enzyme solution.

Also, an enzyme solution was prepared from the cells of 96-hour cultivation and RNA was hydrolyzed at $\mathrm{pH} 4.0$ and 7.3 under the same condition described above. The resulting mononucleotides were analyzed by ion-exchange column chromatography and by the enzymatic assay as before. The results are given in Fig. 10 and Table I. Namely, the degradation products were 3 '-mononucleotides at either $\mathrm{pH}$. The molar proportions of mononucleotides in each enzymatic hydrolyzate of RNA are summarized in Table II.
SCHEME I. Hydrolysis of RNA by Intracellular Enzymes of Rhodotorula glutinis

Enzyme source

Degradation products

$16 \mathrm{hrs}$ cultivated cells $\mathrm{pH} \overparen{\mathrm{pH}} 7.3$

$40 \mathrm{hrs}$ cultivated cells $3^{\prime}$-mononucleotide $5^{\prime}$-mononucleotide $+$ $3^{\prime}$-mononucleotide

96 hrs cultivated cells $3^{\prime}$-mononucleotide $3^{\prime}$-mononucleotide

The above-mentioned results are summarized in scheme I, and from the results it was ascertained that RNA-depolymerase I hydrolyzed RNA into 5'-mononucleotides, and both RNA-depolymerases II and III hydrolyzed RNA into 3'-mononucleotides.

\section{(IV) Products of DNA Hydrolysis.}

In order to estimate the degradation products of DNA, it was hydrolyzed with the sonic extract of the cells which were cultivated for 16 hours in Mix-medium, and the resulting degradation products were analyzed by ionexchange chromatography. Ten $\mathrm{ml}$ of $1.0 \%$

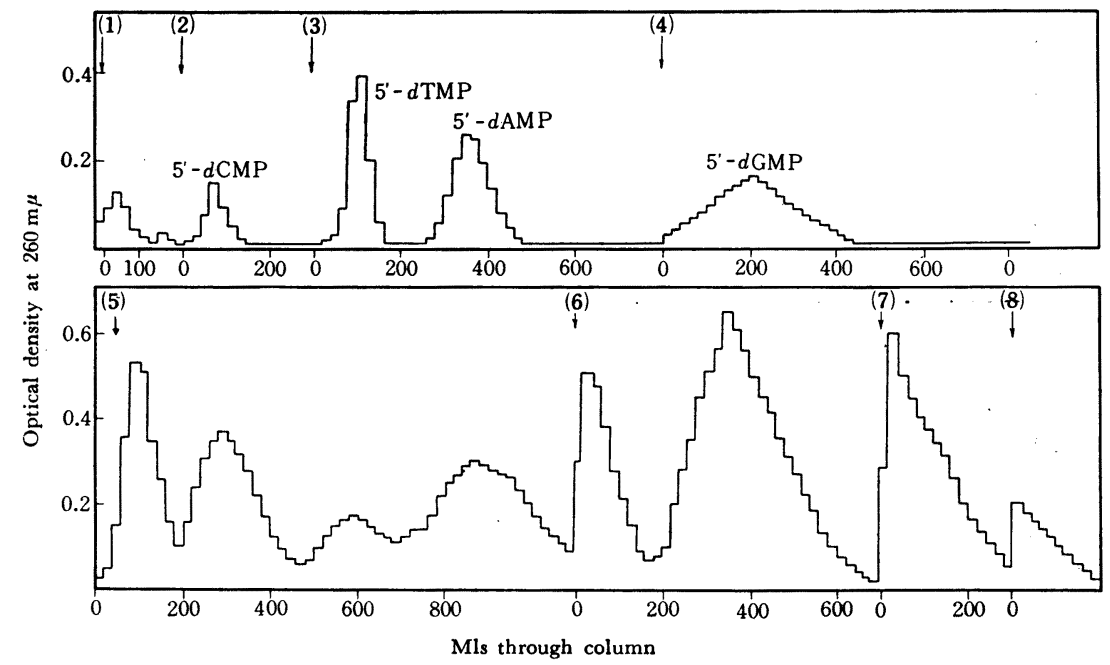

FIG. 11. Separation of Products of DNA-depolymerase Digestion of DNA by Anion Exchanger.

Exchanger, flow rate and fraction size: see Fig. 9.

Eluting solution: Ammonium formate as shown.

Adsorbed material: DNA hydrolyzate by the sonicate of the cells. from 16-hour cultivation.
(1) 0.005 м Formic
(2) $0.03 \mathrm{NH}$-Formate $\mathrm{pH} 4.5$
(3) 0.08 м $\mathrm{NH}_{4}$-Formate $\mathrm{pH} 4.5$
(4) $0.1 \mathrm{~m} \mathrm{NH}$-Formate $\mathrm{pH} 4.5$
(5) 0.25 м $\mathrm{NH}_{4}$-Formate $\mathrm{pH} 4.5$
(6) $0.5 \mathrm{M} \mathrm{NH}_{4}$-Formate $\mathrm{pH} 4.5$
(5) $1.0 \mathrm{M} \mathrm{NH}$-Formate pH 4.5
(8) $2.0 \mathrm{M} \mathrm{NH} 4$-Formate $\mathrm{pH} 4.5$
See text for additional details. 
DNA solution, $20 \mathrm{ml}$ of $0.5 \mathrm{M}$ Tris buffer $(\mathrm{pH} 7.5), 4.0 \mathrm{ml}$ of $0.1 \mathrm{M} \mathrm{MgSO}_{4} \cdot 7 \mathrm{H}_{2} \mathrm{O}$, and $6.0 \mathrm{ml}$ of the enzyme solution were mixed and left standing at $37^{\circ} \mathrm{C}$ for 3 hours. The reaction mixture was then adjusted to $\mathrm{pH} 4.0$ and the precipitate was removed by centrifugation, and by use of the supernatant as a sample, the rate of DNA degradation and 5'-deoxymononucleotide and 3'-deoxymononucleotide formations were measured with the results of $78.0 \%, 11.0 \%$ and $0 \%$, respectively. On the other hand, $20 \mathrm{ml}$ of the supernatant was subjected to the treatment with active charcoal, concentrated to $8.0 \mathrm{ml}$ and half of the concentrate was chromatographed on a Dowex-1 formate column. Figure 11 shows the elution pattern obtained. The deoxymononucleotides were eluted in four discrete peaks which corresponded to $12 \%$ of the ultraviolet-absorbing material originally retained by the column and the greater part of the remainder was eluted in the oligonucleotide fraction.

\section{DISCUSSION}

It has been known that RNA-hydrolyzing enzymes produced by yeast ${ }^{1 \sim 3)}$ degraded RNA into 3'-mononucleotides. In the present work the authors found that there was present in the cells of Rhodotorula glutinis an enzyme which degraded RNA into 5'-mononucleotides.

Variations in the activity of RNases in other microorganisms have already been reported. Suskind and Bonner ${ }^{6)}$ have found that in wild-type strains of Neurospora crassa the RNase-level of mycelia increased with age. On the other hand, Barker and Cannon ${ }^{\text {) }}$ have observed that the RNase content of Micrococcus lysodeikticus was constant during the logarithmic phase of growth and showed a higher and increasing value for

\footnotetext{
6) S.R. Suskind and D.M. Bonner, Biochim. Biophys. Acta, 43, 173 (1960).

7) G.R. Barker and M. Cannon, Biochem J., 75, 8 (1960).
}

a short period in the beginning of the stationary phase. Urbá-Holmgren and Waisberg showed that RNase content increased as the culture aged during the logarithmic phase and the onset of the stationary phase. After reaching a peak, the content decreased to a low level and was kept constant thereafter. However, the authors have so far had little information as to the change in the kind of RNA-depolymerase in the cells during growth. In the present study the authors found that Rhodotorula glutinis, when cultivated in Mix-medium, produced a large amount of RNA-depolymerase I capable of degrading RNA into 5'-mononucleotides at the early logarithmic phase of growth, but when the cultivation was continued, the production of RNA-depolymerases II and III, both of which hydrolyzed RNA into $3^{\prime}$ mononucleotides, took place in parallel with the decrease of RNA-depolymerase I activity.

On the other hand, when the same microorganism was cultivated in NS-medium, RNA-depolymerase I was produced at the logarithmic phase of growth, while RNAdepolymerase II and III were not found in the cells at any stage of growth.

In the previous paper ${ }^{1)}$ the authors reported that Rhodotorula glutinis produced in the medium two kinds of enzyme systems which degraded RNA into 3'-mononucleotides. When the present work is considered together with the results described in the preceding paper, it is assumed that Rhodotorula glutinis cultivated in NS-medium produces RNA-depolymerase II and III in the cells, but they are soon excreted into the medium, while when the microorganism is cultivated in Mix-medium, part of the resulting RNA-depolymerase II and III is excreted into the medium, but majority of them remains in the cells. Therefore, addition of

8) R. Urbá-Holmgren and E. Waisberg S., Nature, 193, 374 (1962). 
the soy bean meal to NS-medium may have a relation with the amount of RNA-depolymerase II and III formed or with the excretion mechanism of these enzymes.

The relationship among the RNA-depolymerases, DNA-depolymerase and phosphodiesterase is discussed as under. RNA-depolymerase I and DNA-depolymerase have much in common. Namely, they are alike in the optimum $\mathrm{pH}$ and both are very active at the early logarithmic phase of growth and less active at the stationary phase of growth. Furthermore, the products of DNA and RNA hydrolysis by each enzyme are $5^{\prime}$-isomers. Therefore, it seems likely that one enzyme capable of cleaving RNA as well as DNA is responsible for both activities, in other words, it has no specificity with respect to the sugar residue of DNA and RNA.

However, an answer to this question must await further purification of the enzymes.

The relation between RNA-depolymerase I and phosphodiesterase is as follows. As is evident from the Figs. 1 and 3, prolonged cultivation results in the decrease of RNAdepolymerase $\mathrm{I}$ activity and the increase of phosphodiesterase activity, so they are considered to be different enzymes.

RNA-depolymerase II and phosphodiesterase are different in their $\mathrm{pH}$ optima, therefore, they are assumed to be different enzymes.

The change in the activity during growth and the optimum $\mathrm{pH}$ of RNA-depolymerase III are similar to those of phosphodiesterase, but the latter is produced in the cells and not excreted in the medium, while the former is excreted in the medium when the microorganism is cultivated in NS-medium. They are also considered to be different enzymes. From the results mentioned above, Rhodotorula glutinis seems to produce a phosphodiesterase which hydrolyzes synthetic substrate, CaDNPP, specifically.

Acknowledgments. The authors should like to express their thanks to Dr. S. Kuwada, Dr. K. Sato, Dr. S. Tatsuoka, Dr. M. Abe, and Dr. E. Omura of Takeda Research Laboratories for interests in the present work and encouragements throughout the study. The technical assistance of Mr. S. Mori is acknowledged with thanks. 